\title{
Zinc Nanoparticles Ameliorate the Reproductive Toxicity Induced by Silver Nanoparticles in Male Rats
}

This article was published in the following Dove Press journal: International Journal of Nanomedicine

\author{
Asmaa M Shehata' \\ Fatma MS Salem' \\ Eiman M El-Saied' \\ Sahar S Abd El-Rahman ${ }^{2}$ \\ Mohamed Y Mahmoud' \\ Peter A Noshy (ID) \\ 'Department of Toxicology and Forensic \\ Medicine, Faculty of Veterinary Medicine, \\ Cairo University, Giza, Egypt; \\ ${ }^{2}$ Department of Pathology, Faculty of \\ Veterinary Medicine, Cairo University, \\ Giza, Egypt
}

Introduction: Silver nanoparticles (Ag-NPs) are among the most commonly used nanoparticles in different fields. Zinc nanoparticles (Zn-NPs) are known for their antioxidant effect. This study was designed to investigate the adverse effects of Ag-NPs (50 nm) on the male reproductive system and also the ameliorative effect of Zn-NPs (100 nm) against these harmful effects.

Methods: Forty adult male rats were used in this study; they were randomly divided into four equal groups: control group, Ag-NPs group, Zn-NPs group, Ag-NPs $+\mathrm{Zn}-\mathrm{NPs}$ group. Ag-NPs $(50 \mathrm{mg} / \mathrm{kg})$ and/or Zn-NPs $(30 \mathrm{mg} / \mathrm{kg})$ were administered orally for 90 days.

Results: The results revealed that exposure to Ag-NPs adversely affected sperm motility, morphology, viability, and concentration. Ag-NPs also induced oxidative stress and lipid peroxidation in testicular tissue. The exposure to Ag-NPs decreased serum FSH, LH, and testosterone hormones. Additionally, comet assay revealed DNA degeneration in the testicular tissue of rats exposed to Ag-NPs. Histopathological examination showed various histological alterations in the testes of rats intoxicated with Ag-NPs. Furthermore, coadministration of Zn-NPs ameliorated most of the toxic effects of Ag-NPs via their antioxidative capacity.

Keywords: antioxidants, DNA damage, endocrinology, oxidative stress, sperm evaluation, testes

\section{Introduction}

Nano-materials have many applications in our daily practices. There are numerous advantages that nanomaterials, including nanoparticles (NPs), bring to the general public, for example in drug delivery networks, clinical devices, food items, and cosmetics. However, NPs expanding utilization raises worry about the dangers that they may cause to people. The danger of dermal, respiratory, and oral exposures to NPs exists at numerous phases of the NPs life cycle. ${ }^{1}$

Among different nanomaterials, silver nanoparticles (Ag-NPs) have become the generally utilized NPs in material science, and consumer items because of their antibacterial properties. ${ }^{2,3}$ Likewise, Ag-NPs are utilized in medication, as one of the constituents of dental combinations, catheters, embedding surfaces, drug delivery in malignancy and retinal treatments, and for treating wounds and burns-related infections. ${ }^{4,5}$ The vast majority of the research inspecting Ag-NPs toxicity is focused on in vitro models. Previous studies stated that Ag-NPs have cytotoxic and proinflammatory impacts, caused basically by the massive production of reactive oxygen
Correspondence: Peter A Noshy Email vet_peter@cu.edu.eg 
species, the release of cytokines, and up-regulation of heat shock proteins. ${ }^{6-8}$ Furthermore, A few reports showed that Ag-NPs instigated apoptosis and necrosis, caused DNA damage, and upset cell cycle progression. ${ }^{9,10}$ Concerning the transfer of Ag-NPs across the blood-testis barrier, Castellini et $\mathrm{al}^{11}$ identified the presence of Ag-NPs in spermatids and ejaculated sperms by transmission electron microscope after intravenous injection in rabbits. Moreover, Van der Zande et $\mathrm{al}^{12}$ and Garcia et $\mathrm{al}^{13}$ suggested that clearance of silver through the blood-testis barrier is difficult, so the testicular silver concentrations were not decreased after cessation of Ag-NPs administration and caused higher toxicity. Yet again, Braydich-Stolle et al and Zhang et al ${ }^{14-16}$ reported inhibition of proliferation and viability of some cells of the testis after treatment with Ag-NPs. Additionally, Tiedemann et $\mathrm{al}^{17}$ built up an in vitro assay for surveying the reproductive toxic impacts of gold and silver NPs on mammalian gametes; they found that Ag-NPs administration induced harmful effects on porcine gametes. In turn, some studies have shown the size and dose-dependent effects of Ag-NPs on rat sperm parameters. ${ }^{18,19}$

Zn-NPs received more attention in commercial and biomedical applications as antibacterial, anti-inflammatory, anticancer, antidiabetic agents, and also for their ability to release zinc ions. ${ }^{20,21}$ Furthermore, Zn-NPs have a significant role in keeping up critical cellular processes like DNA replication, DNA repair, cell division, and protection against oxidative stress. ${ }^{22}$ Moreover, Dani and Dhawan ${ }^{23}$ and Malekirad et $\mathrm{al}^{24}$ stated that $\mathrm{Zn}$ is a protecting antioxidant because of its capacity to bring malondialdehyde (MDA) levels to approach their normal levels. Also, Raajshreer and Durairaj ${ }^{25}$ reported that synthesized ZnO-NPs showed antioxidant activity through chemicalreduction activities and scavenging of free radicals. Recently, Essa et $\mathrm{al}^{26}$ demonstrated that the addition of Zn-NPs to chlorpyrifos-contaminated drinking water was useful as a strong antioxidant agent against chlorpyrifos-induced toxic damage in rats.

Despite the widespread use of Ag-NPs, few in vivo studies have been conducted to investigate their adverse effects on the male reproductive system. Therefore, the present study aims to determine the toxic effects of AgNPs on the male reproductive system of rats and also to explore their potential mechanism of action. Also, up to our knowledge, the ability of Zn-NPs to ameliorate the toxicity of Ag-NPs has not been investigated. So, we sought to assess the ameliorative effect of Zn-NPs against the toxicity of Ag-NPs on the male reproductive system of rats.

\section{Materials and Methods}

\section{Animals}

Forty adult male Sprague-Dawley rats of the same age (3 months) and weighing (200 $\pm 10 \mathrm{~g})$ were used in this study. The animals were obtained from the laboratory animal house at the Faculty of Veterinary Medicine, Cairo University. Rats were maintained in plastic cages and supplied with pelleted feed, and water ad libitum. They were kept under observation and acclimated to the laboratory environment (normal daylight - temperature of $25-30{ }^{\circ} \mathrm{C}$ ) for one week before starting of the experiment. The institutional animal care and use committee at the faculty of veterinary medicine, Cairo University, Giza, Egypt (Vet. Cu. IACUC) approved the experimental design (protocol number: 01102020220). All laboratory animals received humane care in compliance with the guidelines of the National Institutes of Health (NIH).

\section{Chemicals}

Silver nanoparticles (Ag-NPs) were synthesized according to a previously described chemical reduction technique. ${ }^{27,28}$ Briefly, $0.14 \mathrm{M} \mathrm{AgNO}_{3}$ solution (purchased from Science Company ${ }^{\circledR}$ ) was mixed with $0.01 \mathrm{M}$ sodium borohydride and $10 \%$ polyvinyl pyrrolidone (PVP) on ice. The color of the silver solution slowly turned into grayish to deep brown indicating the reduction of the silver ions to nanoparticles. Ag-NPs solution was frozen at $-80^{\circ} \mathrm{C}$ and lyophilized. Zinc nanoparticles were purchased from Nano-Tech, Dreamland, $6^{\text {th }}$ October, Giza, Egypt.

The size and shape of Ag-NPs and Zn-NPs were determined by a high-resolution transmission electron microscope (JEOL, JEM-2100) at an accelerating voltage of 200 $\mathrm{kV}$. Zeta potential and dynamic light scattering analyses were carried out on hydrated NPs to assess the surface charge and hydrodynamic diameter (Malvern, UK).

\section{Experimental Design}

Animals were classified into four equal groups; the groups were treated daily by oral gavage for 3 months as follow:

Group 1 (control group): received distilled water.

Group 2 (Ag-NPs group): received $50 \mathrm{mg} / \mathrm{kg}$ BW of silver nanoparticles. The investigated dose was selected in the range between the NOAEL (no observable adverse effect level) and the LOAEL (lowest observable adverse effect level) which were $30 \mathrm{mg} / \mathrm{kg}$ and $125 \mathrm{mg} / \mathrm{kg}$ respectively. ${ }^{29}$ 
Group 3 (Zn-NPs group): received $30 \mathrm{mg} / \mathrm{kg}$ BW of zinc nanoparticles. The selected size and dose of Zn-NPs are considered safe for rats. ${ }^{30}$

Group 4 (Ag-NPs + Zn-NPs group): received the previously mentioned doses of Ag-NPs and Zn-NPs.

\section{Collection and Preparation of Samples}

At the end of the exposure period, animals were anesthetized by intraperitoneal injection of $90 \mathrm{mg} / \mathrm{kg}$ ketamine $+10 \mathrm{mg} /$ $\mathrm{kg}$ xylazine (in the same syringe). Blood samples were collected from the inner canthus of the eye and serum was separated by centrifugation and stored at $-20{ }^{\circ} \mathrm{C}$. Sperm samples were collected from the tail of the epididymis and used for sperm evaluation. Rats were then euthanized by cervical dislocation for collection of tissue samples; one testis was kept in Bouin's solution for histopathological examination and the other testis was stored at $-20{ }^{\circ} \mathrm{C}$.

Testicular tissue $(1 \mathrm{~g})$ was homogenized in potassium phosphate buffer $(5 \mathrm{~mL})$ using tissue homogenizer followed by centrifugation and collection of the supernatant to be used in the comet assay and for determination of the oxidative stress and lipid peroxidation parameters.

\section{Sperm Evaluation}

Sperm samples were collected by maceration of the tail of the epididymis, and vas deferens and were used for sperm evaluation according to the method described by Bearden and Fuquay. ${ }^{31}$

For mass motility evaluation, a drop of physiological saline was added to the sperm sample on a warm slide followed by examination under the light microscope. For determination of sperm concentration, the sperm sample was diluted by physiological saline and stained with eosin $2 \%$, and sperms were counted using a hemocytometer. ${ }^{32,33}$

Sperms also were examined for viability and different morphological abnormalities. Sperm smears were stained with eosin $1 \%$ and nigrosine 5\%. One hundred sperms were examined in each slide and numbers of live sperms, dead sperms, curved tails, coiled tails, deformed heads, and detached heads were recorded. ${ }^{31}$

\section{Estimation of Antioxidant Enzymes and Lipid Peroxidation Parameters}

Reduced glutathione (GSH), Catalase (CAT), and malondialdehyde (MDA) levels were measured in testicular tissue homogenate using kits obtained from Biodiagnostic Co., Giza, Egypt.

\section{Reduced Glutathione}

GSH concentration was determined according to the method of Beutler et al, ${ }^{34}$ which depends on the reduction of 5,5-dithiosbis-2-nitrobenzoic acid with GSH producing a yellow compound. The intensity of the yellow color is directly proportional to GSH concentration. Absorbance was measured at $405 \mathrm{~nm}$.

\section{Catalase}

CAT activity was determined according to the method of Fossati et al, ${ }^{35}$ which depends on the ability of CAT to destroy $\mathrm{H}_{2} \mathrm{O}_{2}$ followed by the addition of CAT inhibitor to stop the reaction after $1 \mathrm{~min}$. The remaining $\mathrm{H}_{2} \mathrm{O}_{2}$ reacts with 3.5-dichloro-2-hydroxybenzene sulfonic acid and 4-aminophenazone in the presence of peroxidases to produce a chromophore. The color intensity of the chromophore is inversely proportional to CAT activity. Absorbance was measured at $510 \mathrm{~nm}$.

\section{Malondialdehyde}

MDA content was determined according to the method of Livingstone et $\mathrm{al}^{36}{ }^{36}$ which depends on the reaction between MDA and thiobarbituric acid in an acidic medium to produce a reactive colored product. The color intensity of this product is directly proportional to MDA content. Absorbance was measured at $534 \mathrm{~nm}$.

\section{Hormonal Assessment Testosterone Hormone}

Serum testosterone was estimated according to the method described by Demetrious ${ }^{37}$ using a competitive-ELISA kit obtained from Leader Trade Co., Giza, Egypt. Testosterone in the sample competes with a testosterone horseradish peroxidase conjugate for binding to the coated antibodies. Then, a substrate is added and a color develops which is inversely proportional to the concentration of testosterone in the sample.

\section{Luteinizing Hormone ( $\mathrm{LH}$ ) and Follicle-Stimulating Hormone (FSH)}

Serum gonadotropins (LH and FSH) were estimated according to the method described by Beastall ${ }^{38}$ using two different sandwich-ELISA kits obtained from Leader Trade Co., Giza, Egypt. Gonadotropins (LH or FSH) in the sample combine with the antibodies on the solid phase of the ELISA kit. Then, biotinylated detection antibodies specific for different hormones and avidin conjugated to horseradish peroxidase are added. Finally, a substrate is 
added and a color develops which is directly proportional to the concentration of different hormones in the sample.

\section{Comet Assay}

Assessment of DNA damage in testicular tissue was performed using comet assay according to the method of Tice et al. ${ }^{39}$ Testicular tissue homogenate was embedded in agarose gel on a microscope slide. Slides were then placed in a lysing solution composed of $10 \%$ DMSO and $1 \%$ Triton X-100 base for lysing cells and exposing DNA. Subsequently, alkaline electrophoresis was conducted, and slides were stained with ethidium bromide and examined by fluorescence microscope. Comet 5 image analysis software developed by Kinetic Imaging Ltd. (Liverpool, UK) was used for the evaluation of results.

\section{Histopathological Examination}

Twenty-four hours post-fixation in Bouin's solution, the testis was routinely processed through graded alcohol and embedded in paraffin. The paraffin blocks were cut in slices of 4-5 $\mu \mathrm{m}$ thickness and then the obtained sections were stained with Hematoxylin and Eosin (H\&E). ${ }^{40}$ Finally, sections were examined under a light microscope (Olympus, Warsaw, Poland).

Ten seminiferous tubules were randomly selected from each testis and the parameters, including area, circumference, and diameter were determined using image analysis software (ImageJ, 1.46a, NIH, USA).

\section{Statistical Analysis}

The obtained values were presented as mean \pm SD. Comparisons between different groups were carried out by one-way analysis of variance (ANOVA) followed by Tukey post hoc test [SPSS software (version 20)]. A $P$-value less than 0.05 was considered statistically significant.

\section{Results}

\section{Chemicals}

Ag-NPs demonstrated a spherical morphology and their average size measured from TEM images was $50 \mathrm{~nm}$ (Figure 1). Additionally, Zn-NPs showed a spherical morphology with average size $100 \mathrm{~nm}$ obtained from TEM images (Figure 2). The average hydrated diameters of Ag-NPs and Zn-NPs were $113.4 \pm 12.1 \mathrm{~nm}$ and $74.5 \pm 6.4 \mathrm{~nm}$, respectively. Ag-NPs and Zn-NPs had zeta potentials of $-12.30 \pm 0.4 \mathrm{mV}$ and $-4.16 \pm 0.5$ $\mathrm{mV}$, respectively (Table 1).

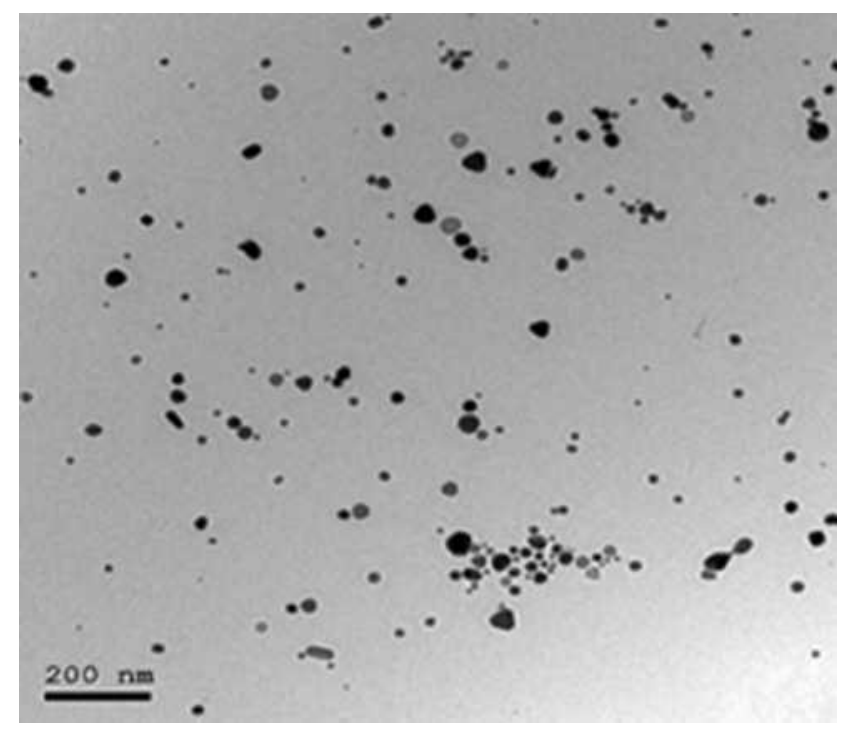

Figure I TEM image of Ag-NPs.

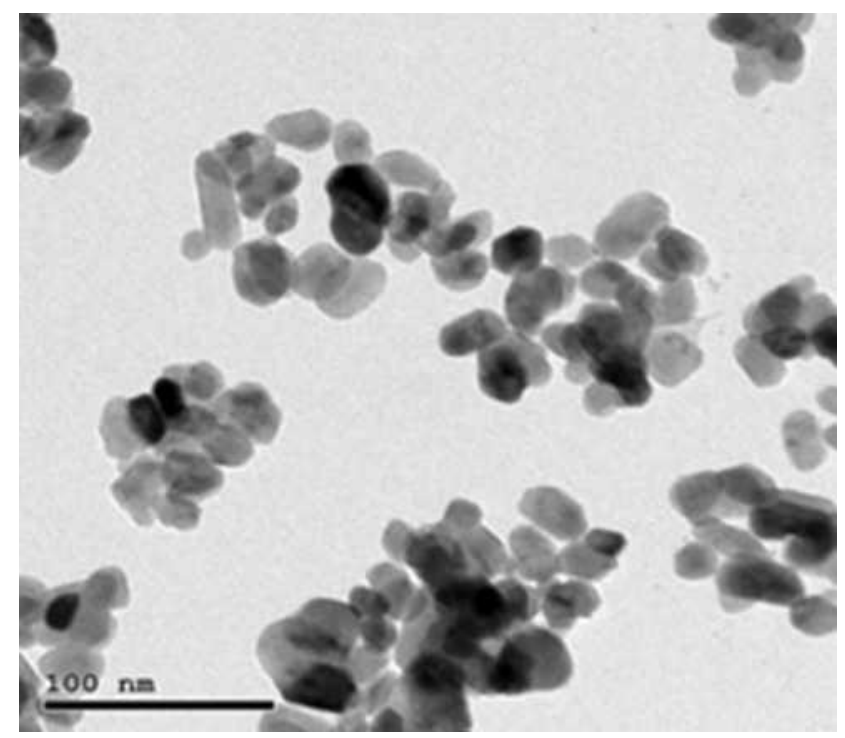

Figure 2 TEM image of Zn-NPs.

\section{Sperm Evaluation}

Sperm Motility, Concentration, and Viability

Exposure to Ag-NPs resulted in a significant decrease in sperm motility, concentration, and viability compared to the control group. While exposure to Zn-NPs resulted in a non-significant change in sperm motility, concentration, and viability compared to the control group. On the other hand, co-administration of Zn-NPs with Ag-NPs resulted in a significant increase in sperm motility, concentration, and viability compared to Ag-NPs group (Table 2). 
Table I Hydrated Diameter (nm) and Zeta Potential (mv) of AgNPs and Zn-NPs

\begin{tabular}{|l|c|c|}
\hline NPs Type & $\begin{array}{c}\text { Hydrated Diameter } \\
(\mathbf{n m})\end{array}$ & $\begin{array}{c}\text { Zeta Potential } \\
(\mathbf{m v})\end{array}$ \\
\hline Ag-NPs & $113.4 \pm 12.1$ & $-12.30 \pm 0.4$ \\
Zn-NPs & $74.5 \pm 6.4$ & $-4.16 \pm 0.5$ \\
\hline
\end{tabular}

Note: Values are presented as mean \pm SD.

Table 2 Effects of Exposure to Ag-NPs and/or Zn-NPs on Sperm Motility (\%), Concentration ( $\times 10^{6} /$ Epididymis), and Live Sperms (\%)

\begin{tabular}{|l|c|c|c|}
\hline Group & Motility & Concentration & Live Sperms \\
\hline Control & $74.7 \pm 5.33$ & $107.5 \pm 9.43$ & $89.6 \pm 2.76$ \\
Ag-NPs & $54 \pm 5.40^{\mathrm{a}}$ & $73.9 \pm 10.76^{\mathrm{a}}$ & $69.3 \pm 3.09^{\mathrm{a}}$ \\
Zn-NPs & $72.9 \pm 6.82^{\mathrm{b}}$ & $105.7 \pm 10.61^{\mathrm{b}}$ & $89 \pm 2.26^{\mathrm{b}}$ \\
Ag-NPs + Zn-NPs & $63.5 \pm 7.52^{\mathrm{ab}}$ & $96.7 \pm 6.07^{\mathrm{b}}$ & $82.9 \pm 1.79^{\mathrm{ab}}$ \\
\hline
\end{tabular}

Notes: Values are presented as mean \pm SD ( $=10$ rats/group). ${ }^{a}$ Indicates presence of a statistically significant difference from the control group and indicates presence of a statistically significant difference from Ag-NPs group at $p<0.05$.

\section{Morphological Abnormalities}

Ag-NPs induced a significant increase in sperm morphological abnormalities in comparison with the control group. While exposure to Zn-NPs resulted in a nonsignificant change in sperm morphological abnormalities compared to the control group. Moreover, concurrent administration of $\mathrm{Zn-NPs}$ with Ag-NPs resulted in a significant decrease in sperm morphological abnormalities in comparison with the group that received Ag-NPs only (Table 3) (Figures 3 and 4).

\section{Antioxidant Enzymes and Lipid Peroxidation in Testicular Tissue}

Ag-NPs induced a non-significant change in GSH concentration, a significant decrease in CAT activity and a significant increase in MDA content in testicular tissue compared to the

Table 3 Effects of Exposure to Ag-NPs and/or Zn-NPs on Sperm Morphological Abnormalities (\%)

\begin{tabular}{|l|c|c|c|c|}
\hline Group & $\begin{array}{c}\text { Deformed } \\
\text { Head }\end{array}$ & $\begin{array}{c}\text { Detached } \\
\text { Head }\end{array}$ & Coiled Tail & $\begin{array}{c}\text { Curved } \\
\text { Tail }\end{array}$ \\
\hline Control & $1.54 \pm 0.39$ & $1.60 \pm 0.18$ & $1.57 \pm 1.09$ & $1.86 \pm 0.36$ \\
Ag-NPs & $6.42 \pm 1.11^{\mathrm{a}}$ & $7.52 \pm 1.12^{\mathrm{a}}$ & $5.98 \pm 1.22^{\mathrm{a}}$ & $6.07 \pm 0.94^{\mathrm{a}}$ \\
Zn-NPs & $1.48 \pm 0.40^{\mathrm{b}}$ & $1.68 \pm 0.21^{\mathrm{b}}$ & $1.31 \pm 0.45^{\mathrm{b}}$ & $1.69 \pm 0.37^{\mathrm{b}}$ \\
Ag-NPs + Zn-NPs & $2.41 \pm 0.34^{\mathrm{ab}}$ & $2.15 \pm 0.53^{\mathrm{b}}$ & $2.54 \pm 0.68^{\mathrm{b}}$ & $2.80 \pm 0.48^{\mathrm{ab}}$ \\
\hline
\end{tabular}

Notes: Values are presented as mean \pm SD $\left(n=10\right.$ rats/group). ${ }^{a}$ Indicates presence of a statistically significant difference from the control group and indicates presence of a statistically significant difference from Ag-NPs group at $p<0.05$. control group. While there was no significant difference in oxidative stress and lipid peroxidation parameters between the control group and Zn-NPs group. Otherwise, administration of Zn-NPs with Ag-NPs resulted in a non-significant change in GSH concentration, a significant increase in CAT activity, and a significant decrease in MDA content compared to Ag-NPs group (Figure 5).

\section{Serum Hormones}

Ag-NPs induced a significant decrease in serum testosterone, FSH, and LH compared to the control group. While exposure to $\mathrm{Zn}$-NPs resulted in a non-significant change in serum hormones compared to the control group. On the other hand, concurrent administration of Zn-NPs and Ag-NPs resulted in a significant increase in serum hormones compared to the group that received Ag-NPs only (Figure 6).

\section{Comet Assay on Testicular Tissue}

Ag-NPs induced a significant increase in all comet assay parameters except the percent of DNA in tail that was nonsignificantly different compared to the control group. While the group that received Zn-NPs only showed a nonsignificant change in all comet assay parameters compared to the control group. Furthermore, the administration of $\mathrm{Zn}$ NPs with Ag-NPs showed a significant decrease in tail length and percent of DNA damage, while other parameters were non-significantly changed, in comparison with the group that exposed to Ag-NPs only (Table 4) (Figure 7).

\section{Histopathological Examination}

Microscopic examination of testes of control rats revealed normal histological structure (Figure 8A) of densely packed seminiferous tubules with spermatogonial cells' layers. Moreover, testicular tissue of Zn-NPs administrated rats showed normal appearance of spermatogonial cells' layers with active spermatogenesis along most of the seminiferous tubules (Figure 8B). While testicular tissue of Ag-NPs administered rats revealed marked histological alterations. Thickening of the testicular capsule (tunica albuginea) was observed with congested capsular blood vessels which showed thickening and edema of their walls (Figure 8C). The seminiferous tubules showed disorganized spermatogonial cells' layers with disorganized, widely separated, and detached germinal epithelium from the basement membrane and mild interstitial edema (Figure 8D). Most of the spermatogonial cells showed degenerative changes, pyknotic nuclei, and necrosis (Figure 8E) with some exfoliated cells. Generally, most of the seminiferous tubules showed 

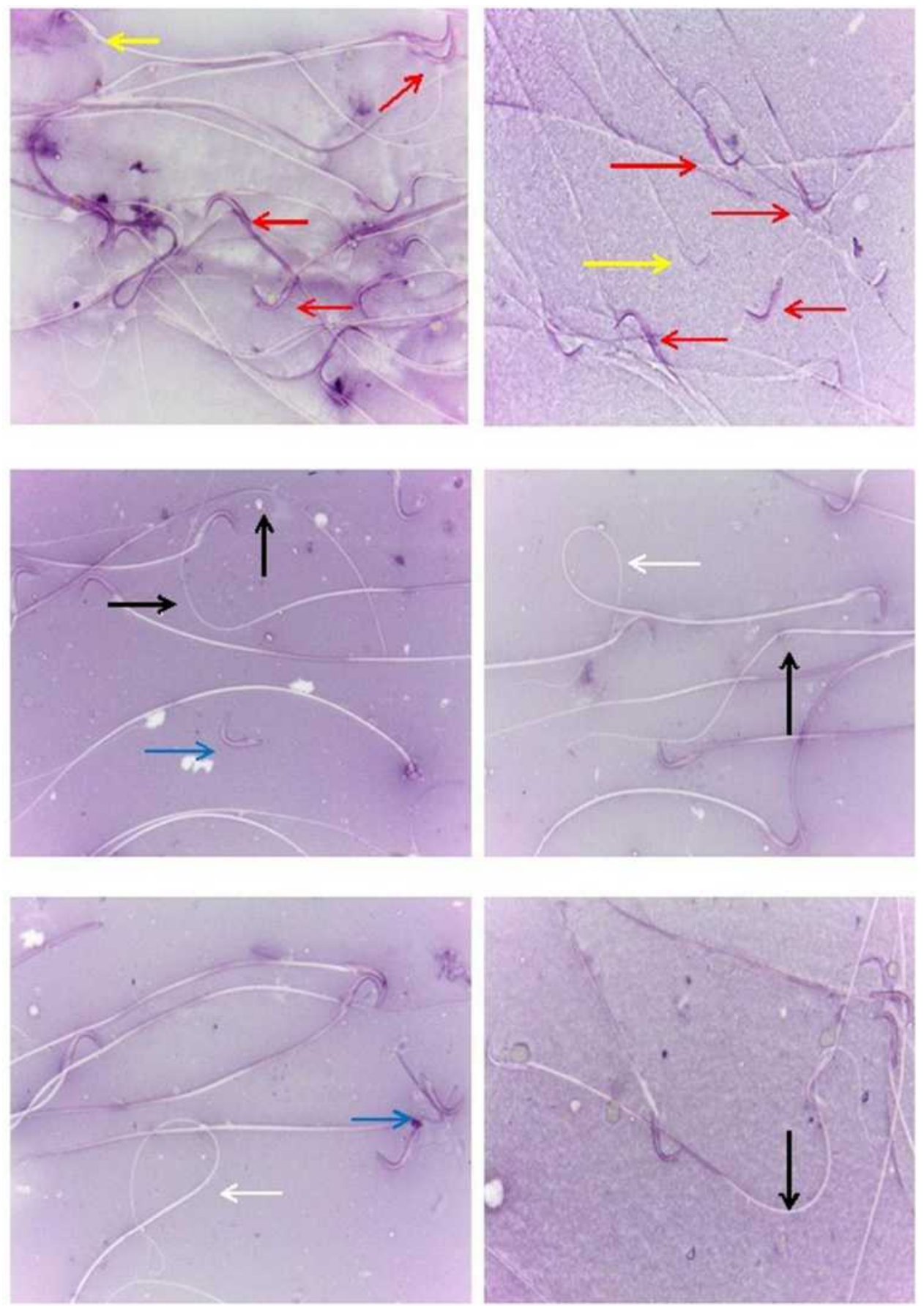

Figure 3 Sperms of rats exposed to Ag-NPs showing an increased incidence of head and tail deformities and decreased viability: live sperm (yellow arrow), dead sperm (red arrow), coiled tail (white arrow), curved tail (black arrow) and detached head (blue arrow).

defective spermatogenesis and cellular loss with the appearance of multinucleated spermatid giant cells (Figure 8F) in some tubules. The interstitium showed a presence of acidophilic vacuolated hyaline material. Some seminiferous tubules appeared with irregular contour with a marked wideness of the spaces between the tubules (Figure 8G) and disorganized separated germinal epithelium from their basement membranes distorted and separated by wide spaces. Whereas the testes of Ag-NPs and Zn-NPs coadministrated rats showed near to normal appearance of the testicular tissue with preservation of the normal histological structure of most of the spermatogonial cells' layers, spermatogenesis (Figure $8 \mathrm{H}$ and I) within the seminiferous tubules and mild edema in inter-tubular space. 

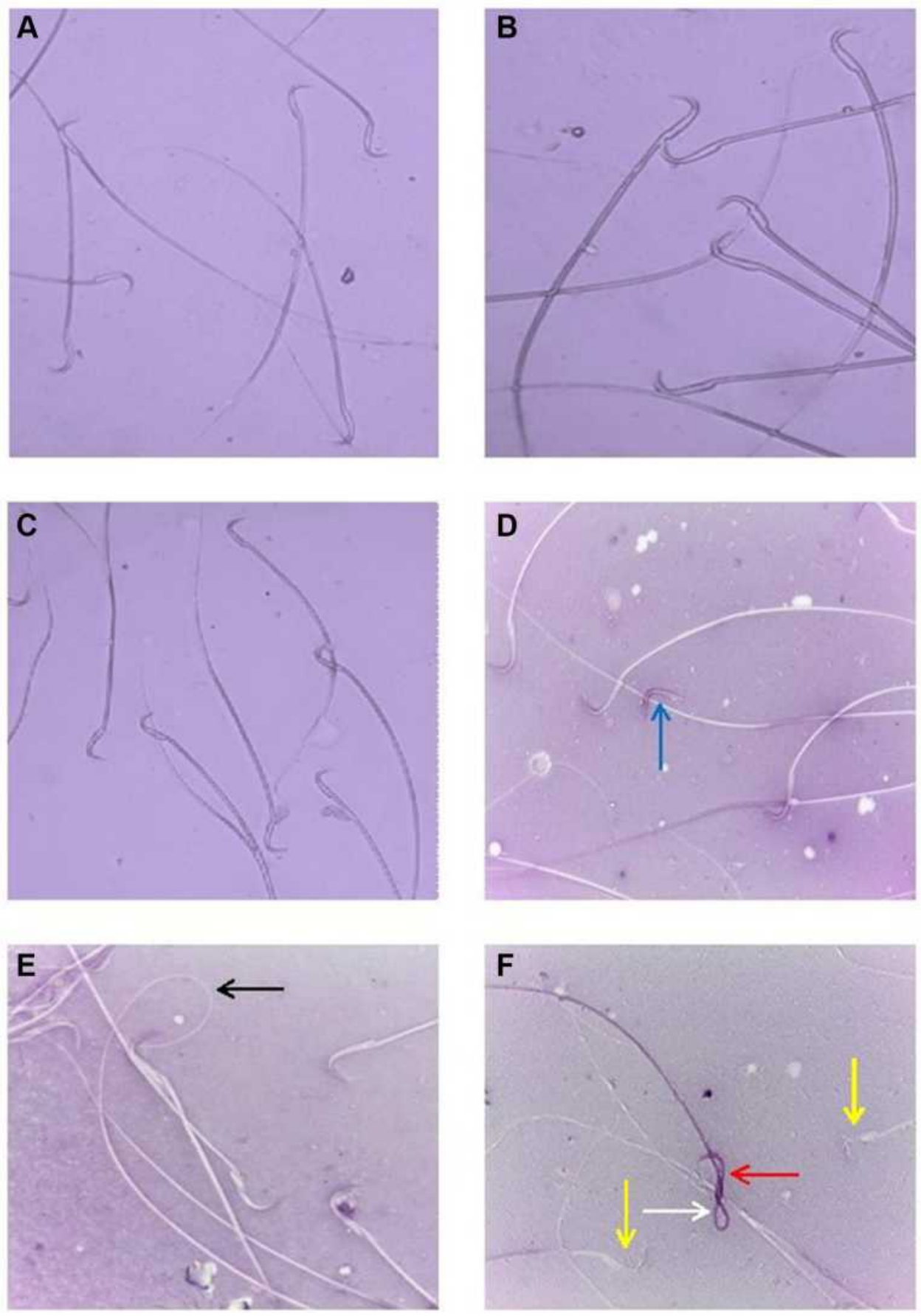

Figure 4 (A, B) sperms of control rats showing normal morphology; (C) sperms of rats exposed to Zn-NPs showing normal morphology; (D-F) sperms of rats exposed to Ag-NPs and Zn-NPs showing a decreased incidence of head and tail deformities and increased viability compared to Ag-NPs group: live sperm (yellow arrow), dead sperm (red arrow), coiled tail (white arrow), curved tail (black arrow) and detached head (blue arrow).

Regarding the results of the morphometric analysis, a significant reduction in the area, circumference and mean diameter of seminiferous tubules was observed in the Ag-NPs group compared to the control group. Zn-NPs administrated group was non-significantly different from the control group. While, a significant amendment in the measured parameters was noticed in the combined Ag-NPs and $\mathrm{Zn}$-NPs group compared to Ag-NPs administrated group (Table 5).

\section{Discussion}

Nanoparticles, including Ag-NPs, have become an important part of daily life and this directed the scientist's trials 
A

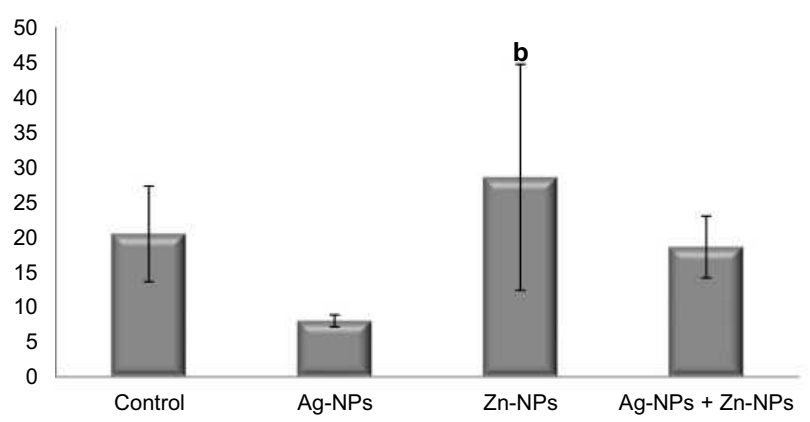

\section{B}

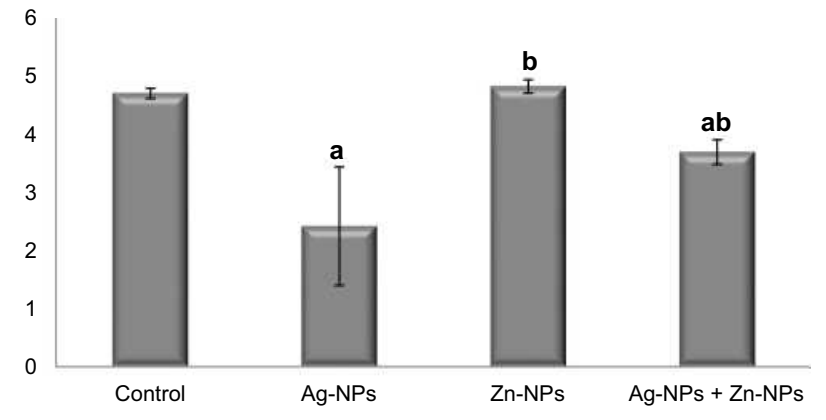

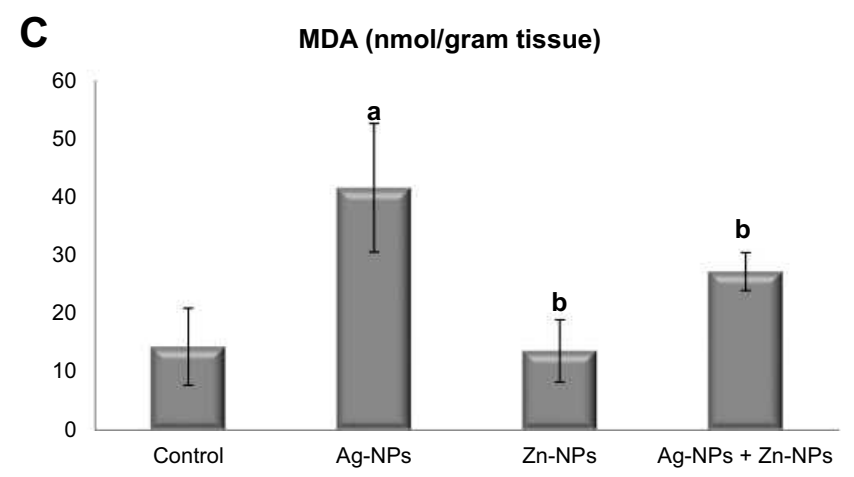

Figure 5 Effects of exposure to Ag-NPs and/or Zn-NPs on (A) GSH, (B) CAT, and (C) MDA levels in testicular tissue. Values are presented as mean \pm SD ( $\mathrm{n}=10$ rats/ group). (a) indicates presence of a statistically significant difference from the control group and (b) indicates presence of a statistically significant difference from Ag-NPs group at $p<0.05$.
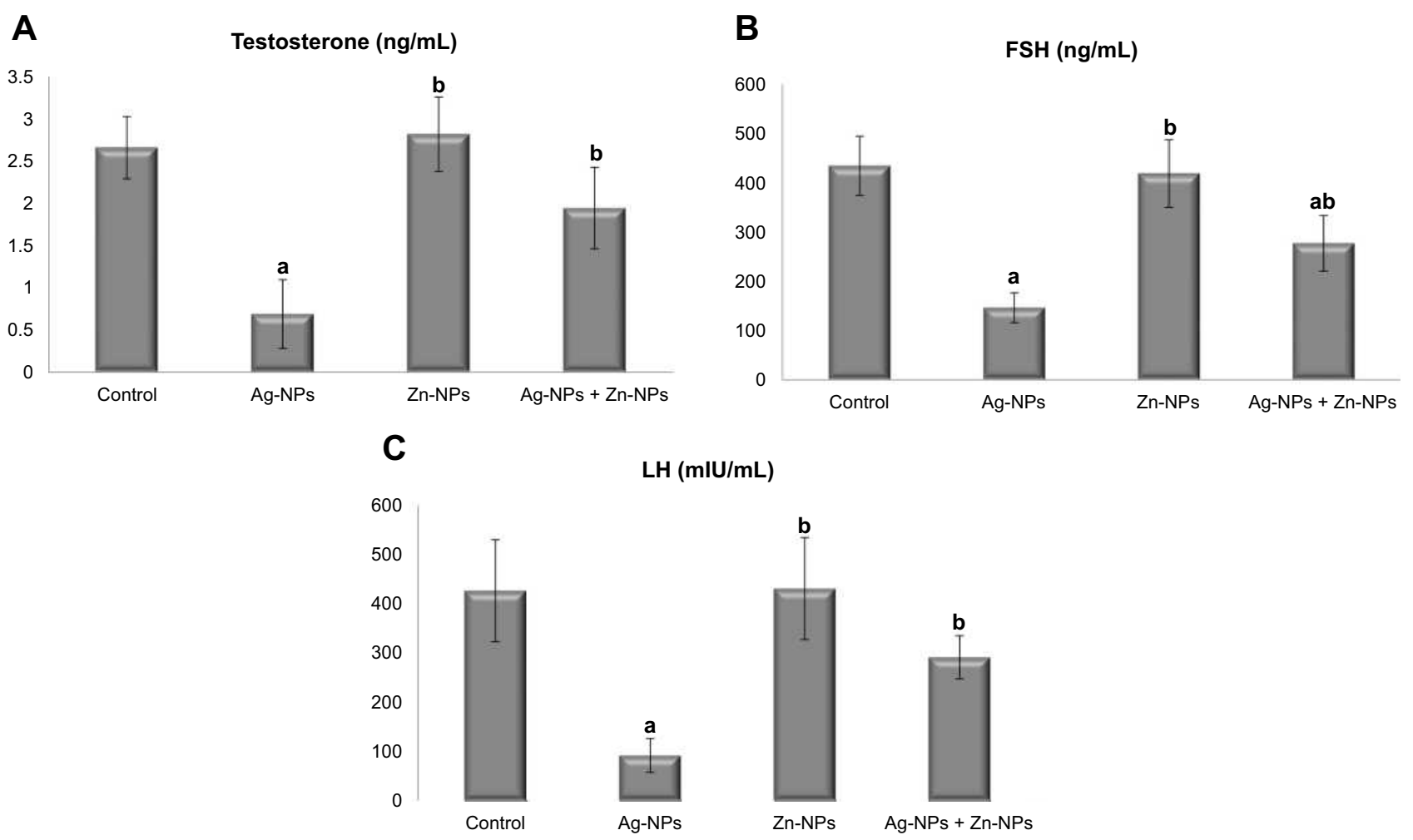

Figure 6 Effects of exposure to Ag-NPs and/or Zn-NPs on $(\mathbf{A})$ testosterone, $(\mathbf{B}) \mathrm{FSH}$, and $(\mathbf{C})$ LH levels in serum. Values are presented as mean \pm SD ( $\mathrm{n}=10$ rats/group). (a) indicates presence of a statistically significant difference from the control group and (b) indicates presence of a statistically significant difference from Ag-NPs group at $p<$ 0.05 . 
Table 4 Effects of Exposure to Ag-NPs and/or Zn-NPs on Comet Assay Parameters on Testicular Tissue

\begin{tabular}{|l|c|c|c|c|c|}
\hline Group & Damage (\%) & Tail Length (px) & DNA in Tail (\%) & Tail Moment & $\begin{array}{c}\text { Olive Tail } \\
\text { Moment }\end{array}$ \\
\hline Control & $10.33 \pm 2.38$ & $7.13 \pm 0.15$ & $10.15 \pm 1.51$ & $0.75 \pm 0.09$ & $1.49 \pm 0.43$ \\
Ag-NPs & $18.50 \pm 0.82^{\mathrm{a}}$ & $18.25 \pm 4.45^{\mathrm{a}}$ & $13.44 \pm 1.67$ & $2.08 \pm 0.85^{\mathrm{a}}$ & $2.49 \pm 0.34^{\mathrm{a}}$ \\
Zn-NPs & $9.03 \pm 1.50^{\mathrm{b}}$ & $6.64 \pm 0.34^{\mathrm{b}}$ & $7.87 \pm 2.55^{\mathrm{b}}$ & $0.67 \pm 0.10^{\mathrm{b}}$ & $1.52 \pm 0.24^{\mathrm{b}}$ \\
Ag-NPs + Zn-NPs & $13.33 \pm 0.32^{\mathrm{b}}$ & $7.78 \pm 0.30^{\mathrm{b}}$ & $9.80 \pm 0.59$ & $0.97 \pm 0.17$ & $1.96 \pm 0.08$ \\
\hline
\end{tabular}

Notes: Values are presented as mean \pm SD ( $n=10$ rats/group). ${ }^{a}$ Indicates presence of a statistically significant difference from the control group and ${ }^{b}$ indicates presence of a statistically significant difference from Ag-NPs group at $p<0.05$.

to find out the possible mechanisms, benefits, and adverse effects of these materials.

The current study demonstrated that when male rats were orally intoxicated with $50 \mathrm{mg} / \mathrm{kg}$ Ag-NPs $(50 \mathrm{~nm}$ ) for 90 days, we showed a significant decrease in sperm concentration, viability, and motility and a significant increase in the incidence of sperm abnormalities. Besides, a significant decrease in serum hormones and testicular antioxidants was observed. Moreover, a significant increase in MDA, DNA degeneration, and histological alterations, was demonstrated.

Consistent with our results, several studies reported that exposure to Ag-NPs resulted in a decrease in sperm motility and an increase in sperm abnormalities. ${ }^{41-43}$ Recently, Fathi et $\mathrm{al}^{44}$ mentioned that exposure to AgNPs decreases sperm concentration and viability. Besides, Carlson et $\mathrm{al}^{45}$ performed an in vitro study and found that mitochondrial activity of macrophages was decreased after exposure to Ag-NPs, which is important for sperm viability and is essential for sperm production and testicular structure in rats. ${ }^{46}$

Reactive oxygen species (ROS) are normally produced as a result of cellular metabolism. They are highly reactive and can cause damage to different cellular structures. The body cells can protect themselves from free radicals by their natural antioxidants. Under normal conditions, there is a balance between ROS and antioxidants, but overproduction of ROS leads to a shift in this balance and this is known as oxidative stress. ${ }^{47}$ The cellular antioxidants are either enzymatic such as catalase (CAT) or non-enzymatic such as reduced glutathione (GSH). CAT is responsible for the destruction of $\mathrm{H}_{2} \mathrm{O}_{2}$ and it also binds to NADPH for enzyme protection from oxidative inactivation. ${ }^{48} \mathrm{GSH}$ acts as a co-substrate for the antioxidative enzymes (glutathione peroxidase and glutathione-S-transferase) and it also scavenges free radicals through its SH group. ${ }^{49-52}$

$\mathrm{Nel}$ et $\mathrm{al}^{53}$ and Bressan et $\mathrm{al}^{54}$ conducted trials to find out the mechanism of toxicity of Ag-NPs and they found that Ag-NPs cause mitochondrial damage and negatively affect the cell respiratory chain leading to the generation of ROS and oxidative stress. ROS generated after exposure to Ag-NPs have an adverse effect on sperms and may be the cause of the observed sperm abnormalities either through a direct effect on the membrane and flagellum of the sperm or an indirect effect on the epididymis. ${ }^{55,56}$ Additionally, ROS can disrupt the lipid bilayer of the cell membrane and induce lipid peroxidation resulting in the production of some products, including malondialdehyde (MDA). ${ }^{57}$ Consequently, the MDA level can be used as an indicator of cell damage due to oxidative stress. For the detection of oxidative stress and lipid peroxidation in testicular tissue, we have measured the levels of CAT and GSH and it was found that exposure to Ag-NPs decreases the levels of testicular antioxidants and increases MDA content. These results are in agreement with the results demonstrated by Arisha et $\mathrm{al}^{58}$ and Elsharkawy et al. ${ }^{59}$

The endocrine control of reproduction in male starts with the secretion of GnRH from the hypothalamus, which stimulates the pituitary gland to synthesize and secrete gonadotropins ( $\mathrm{LH}$ and FSH). Under the stimulation of LH, Leydig cells secrete testosterone which acts with FSH to regulate the function of Sertoli cells. ${ }^{60,61}$ The observed decrease in sperm concentration may result from the decrease in FSH and testosterone levels. The results of this study showed that exposure to Ag-NPs induced a decrease in the levels of FSH, LH, and testosterone. In line with these results, several studies reported a change in FSH, LH, and testosterone following exposure to AgNPs. ${ }^{41,58,59,62}$ The decreased levels of LH and FSH may result from Ag-NPs-induced damage of the hypothalamus or the pituitary gland. According to Trickler et al, ${ }^{63} \mathrm{Ag}$ NPs increase the permeability of the blood-brain barrier and can easily cross it and cause damage to these glands.

The comet assay is frequently used as a rapid, sensitive, and quantitative method for the detection of DNA 

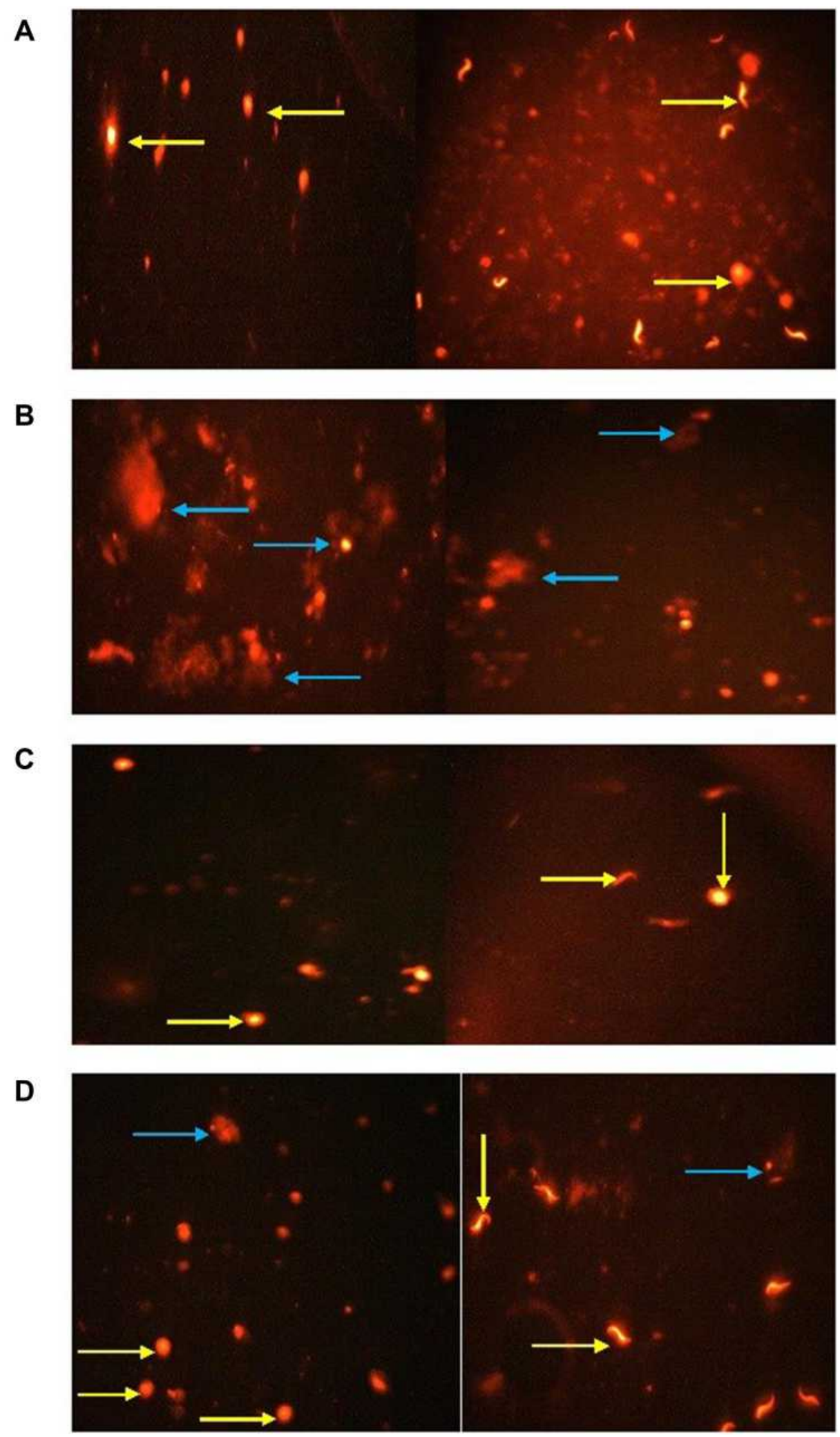

Figure 7 Comet assay in testicular tissue of rats showing the effects of exposure to Ag-NPs and/or Zn-NPs on DNA damage: (A) control group; (B) Ag-NPs group; (C) ZnNPs group; (D) Ag-NPs + Zn-NPs group. Yellow arrow indicates a nucleus without tail (intact DNA). Blue arrow indicates a nucleus with tail (DNA break). 


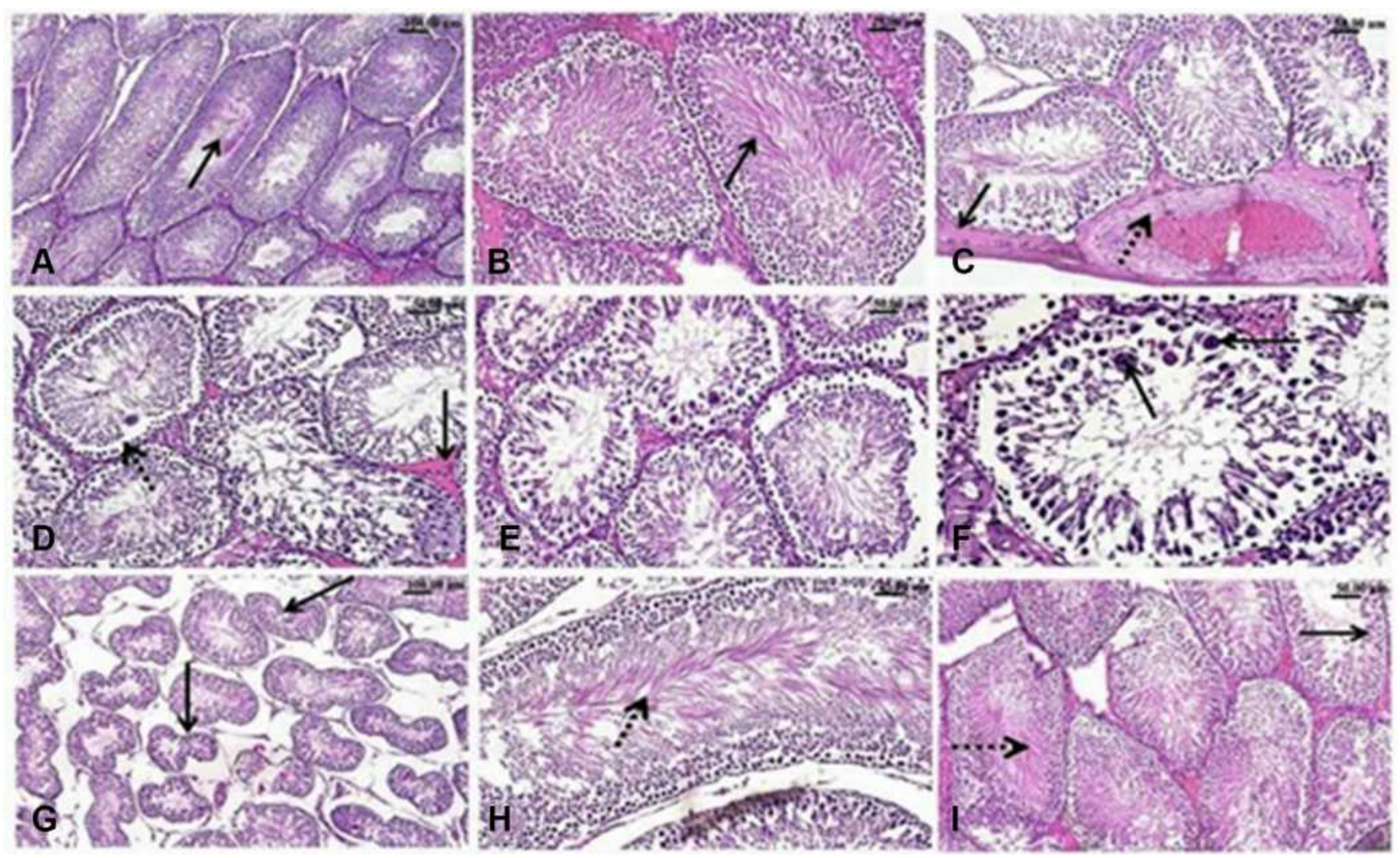

Figure 8 H\&E-stained testicular sections. Effect of exposure to Ag-NPs and/or Zn-NPs on the microscopic appearance of testicular tissue. (A) Testis of control rat showing normal seminiferous tubules with densely packed spermatogonial cells' layers, spermatogenesis and normal sperms in the lumen (arrow). (B) Testis of Zn-NPs administered rat showing normal seminiferous tubules with active spermatogenesis. (C-G) testis of Ag-NPs administrated rat showing; (C) Thickening of the testicular capsule (arrow) and congested capsular blood vessels with thickening and edema (dotted arrow) of their walls, (D) Disorganized spermatogonial cells' layers and detached germinal epithelium (dotted arrow) from the basement membrane of the seminiferous tubules and mild interstitial edema (arrow), (E) Degeneration, necrosis and nuclear pyknosis of the spermatogonial cells, (F) Defective spermatogenesis and presence of multinucleated spermatid giant cells (arrow), (G) Seminiferous tubules appeared with irregular contour (arrow) of seminiferous tubules with marked wide spaces between them. (H and I) Testis of Ag-NPs and Zn-NPs co-administered rat showing near to normal appearance of seminiferous tubules with active spermatogenesis, active sperms (dotted arrow) in the lumen of seminiferous tubules and spermatogonial cells (arrow).

damage in eukaryotic cells. It is based on the measurement of broken DNA strands extending from the cell nucleus during electrophoresis. ${ }^{64}$ In the present study, exposure to Ag-NPs increased DNA damage as indicated by an increase in all comet assay parameters in testicular tissue. Several studies demonstrated that the increased production of ROS and the interruption of ATP synthesis are the causes of DNA damage. ${ }^{8,65,66}$
Ag-NPs can cross the blood-testis barrier ${ }^{12,67}$ causing histological alterations and necrosis. Our results are consistent with the results of Arisha et $\mathrm{al}^{58}$ who demonstrated that oral exposure to Ag-NPs for 8 weeks resulted in alterations of the normal histological structure of testes. Additionally, Thakur et $\mathrm{al}^{68}$ found many pathological lesions, including atrophy of seminiferous tubules and disorganization of germinal epithelium, after oral exposure to Ag-NPs for 90 days.

Table 5 Effects of Exposure to Ag-NPs and/or Zn-NPs on Morphometric Parameters of Seminiferous Tubules Including Area, Circumference, and Mean Diameter

\begin{tabular}{|l|c|c|c|}
\hline Group & $\begin{array}{c}\text { Area } \\
\left(\times 1 \mathbf{0}^{-\mathbf{8}} \mathbf{~ m}^{\mathbf{2}}\right)\end{array}$ & $\begin{array}{c}\text { Circumference } \\
\left(\times 1 \mathbf{0}^{-3} \mathbf{~ m}\right)\end{array}$ & $\begin{array}{c}\text { Mean Diameter } \\
\left(\times 1 \mathbf{0}^{-3} \mathbf{~ m}\right)\end{array}$ \\
\hline Control & $8.69 \pm 0.635$ & $1.198 \pm 0.107$ & $0.333 \pm 0.009$ \\
Ag-NPs & $7.23 \pm 0.426^{\mathrm{a}}$ & $1.086 \pm 0.031^{\mathrm{a}}$ & $0.298 \pm 0.020^{\mathrm{a}}$ \\
Zn-NPs & $9.02 \pm 0.412^{\mathrm{b}}$ & $1.228 \pm 0.035^{\mathrm{b}}$ & $0.329 \pm 0.006^{\mathrm{b}}$ \\
Ag-NPs + Zn-NPs & $8.25 \pm 0.460^{\mathrm{b}}$ & $1.194 \pm 0.019^{\mathrm{b}}$ & $0.324 \pm 0.005^{\mathrm{b}}$ \\
\hline
\end{tabular}

Notes: Values are presented as mean \pm SD $\left(n=10\right.$ rats/group). ${ }^{a}$ Indicates presence of a statistically significant difference from the control group and ${ }^{b}$ indicates presence of a statistically significant difference from Ag-NPs group at $p<0.05$. 
The direct effect of Ag-NPs on testicular cells, including Leydig cells, may be the cause of decreased testosterone in addition to the effect of decreased LH level.

Otherwise, administration of Zn-NPs with Ag-NPs showed an improvement in spermogram and histological appearance of the testes, in addition to a decrease in oxidative stress, lipid peroxidation, and DNA damage, and an increase in levels of serum hormones. All these protective results may be due to the androgenic and antioxidant effects of Zn-NPs which in turn decreases ROS generation and ameliorates the effect of Ag-NPs. Several studies demonstrated the antioxidative and androgenic properties of Zn-NPs. El-Maddawy and Abd El Naby ${ }^{69}$ reported that Zn-NPs ameliorated the adverse effects of doxorubicin, improved reproductive parameters, and increase testosterone level. Yet again, Mohamed and Abdelrahman ${ }^{70}$ also mentioned that administration of Zn-NPs with nicotine ameliorated the undesirable effects of nicotine, decreased oxidative stress, and increased LH, FSH, and testosterone levels. Moreover, Essa et $\mathrm{al}^{26}$ reported that Zn-NPs have an antioxidant effect against chlorpyrifos-contaminated drinking water. Additionally, Fathi et $\mathrm{al}^{71}$ mentioned that Zn-NPs decreased the level of MDA and increased superoxide dismutase and glutathione peroxidase enzymes in broiler chickens.

\section{Conclusion}

We concluded that exposure to Ag-NPs for 90 days resulted in obvious adverse effects on sperm morphology, concentration, motility, and viability. Ag-NPs also induced oxidative stress, DNA damage, and pathological injuries in testicular tissue. Moreover, the level of serum reproductive hormones was reduced following exposure to Ag-NPs. On the other hand, concurrent administration of Zn-NPs mitigated the toxic effects induced by Ag-NPs as indicated by an improvement in sperm parameters, serum hormones, and histopathological picture; in addition to a decrease in oxidative stress and DNA damage in testicular tissue possibly due to the antioxidative properties of Zn-NPs.

\section{Funding}

This research work was financially supported by Cairo University.

\section{Disclosure}

The authors declare no conflicts of interest for this work.

\section{References}

1. Johnston HJ, Hutchison G, Christensen FM, Peters S, Hankin S, Stone V. A review of the in vivo and in vitro toxicity of silver and gold particulates: particle attributes and biological mechanisms responsible for the observed toxicity. Crit Rev Toxicol. 2010;40 (4):328-346.

2. Silvestry-Rodriguez N, Sicairos-Ruelas EE, Gerba CP, Bright KR. Silver as a disinfectant. Rev Environ Contam Toxicol. 2007;191: 23-45.

3. Marambio-Jones C, Hoek EMV. A review of the antibacterial effects of silver nanomaterials and potential implications for human health and the environment. J Nanoparticle Res. 2010;12:1531-1551.

4. Samuel U, Guggenbichler JP. Prevention of catheter-related infections: the potential of a new nano-silver impregnated catheter. Int $J$ Antimicrob Agents. 2004;1:75-78.

5. Kalishwaralal K, Barathmanikanth S, Pandian SR, Deepak V, Gurunathan S. Silver nano- a trove for retinal therapies. J Controlled Release. 2010;145(2):76-90.

6. Sung JH, Ji JH, Park JD, et al. Subchronic inhalation toxicity of silver nanoparticles. Toxicol Sci. 2009;108:452-461.

7. Daniel SCGK, Tharmaraj V, Sironman TA, Pitchumani K. Toxicity and immunological activity of silver nanoparticles. Appl Clay Sci. 2010;48(4):547-551.

8. Kruszewski M, Brzoska K, Brunborg G, et al. Toxicity of silver nanomaterials in higher eukaryotes. Advan Mol Toxicol. 2011;5:179-218.

9. Wijnhoven SWP, Peijnenburg WJGM, Herberts CA, et al. Nanosilver-a review of available data and knowledge gaps in human and environmental risk assessment. Nanotoxicology. 2009;3(2):109-138.

10. Lankoff A, Sandberg WJ, Wegierek-Ciuk A, et al. The effect of agglomeration state of silver and titanium dioxide nanoparticles on cellular response in HepG2, A549 and THP-1 cells. Toxicol Lett. 2012;208(3):197-213.

11. Castellini C, Ruggeri S, Mattioli S, Bernardini G, Macchioni L, Moretti E. Long-term effects of silver nanoparticles on reproductive activity of rabbit buck. Syst Biol Reprod Med. 2014;60(3):143-150.

12. Van der Zande M, Vandebriel RJ, Doren EV, Kramer E, Rivera ZH, Serrano-Rojero CS. Distribution, elimination and toxicity of silver nanoparticles and silver ions in rats after 28-day oral exposure. ACS Nano. 2012;6(8):7427-7442.

13. Garcia TX, Costa GMJ, Franc LR, Hofmann MC. Sub-acute intravenous administration of silver nanoparticles in male mice alters Leydig cell function and testosterone levels. Reprod Toxicol. 2014;45:59-70.

14. Braydich-Stolle LK, Lucas B, Schrand A, et al. Silver-nanoparticles disrupt GDNF/Fyn kinase signaling in spermatogonial stem cells. Toxicol Sci. 2010;116(2):577-589.

15. Zhang T, Wang L, Chen Q, Chen C. Cytotoxic potential of silver nanoparticles. Yonsei Med J. 2014;55(2):283-291.

16. Zhang XF, Choi Y, Han JW, et al. Differential nanoreprotoxicity of silver nanoparticles in male somatic cells and spermatogonial stem cells. Int J Nanomed. 2015;10:1335-1357.

17. Tiedemann D, Taylor U, Rehbock C, et al. Reprotoxicity of gold, silver, and gold-silver alloy nanoparticles on mammalian gametes. Analyst. 2014;139(5):931-942.

18. Gromadzka-Ostrowska J, Dziendzikowska K, Lankoff A, et al. Silver nanoparticles effects on epididymal sperm in rats. Toxicol Lett. 2012;214(3):251-258.

19. Miresmaeili SM, Halvaei I, Fesahat F, Fallah A, Nikonahad N, Taherinejad M. Evaluating the role of silver nanoparticles on acrosomal reaction and spermatogenic cells in rat. Iran J Reprod Med. 2013;11(5):423-430.

20. Osmond MJ, Mccall MJ. Zinc oxide nanoparticles in modern sunscreens: an analysis of potential exposure and hazard. Nanotoxicology. 2010;4(1):15-41. 
21. Jiang J, Pi J, Cai J. The advancing of Zinc Oxide nanoparticles for biomedical applications. Bioinorg Chem Appl. 2018. doi:10.1155/ 2018/1062562

22. Roy B, Baghel RPS, Mohanty TK. Zinc and male reproduction in domestic animals: a review. Indian J Anim Nutr. 2013;30 (4):339-350.

23. Dani V, Dhawan DK. Radioprotective role of zinc following single-dose radioiodine (131I) exposure to red blood cells of rats. Indian J Med Res. 2005;122(4):338-342.

24. Malekirad AA, Oryan S, Fani A, et al. Study on clinical and biochemical toxicity biomarkers in a zinc-lead mine workers. Toxicol Ind Health. 2010;26(6):331-337.

25. Raajshreer K, Durairaj B. Evaluation of the anti-tyrosinase and antioxidant potential of Zinc Oxide nanoparticles synthesized from the brown seaweed - turbinaria conoides. Int J Appl Pharm. 2017;9 (5):116-120.

26. Essa SS, El-Saied EM, El-Tawil OS, Gamal IM, Abd EL-Rahman SS. Nanoparticles of zinc oxide defeat chlorpyrifos-induced immunotoxic effects and histopathological alterations. Veterinary World. 2019;12(3):440-448.

27. Lee PC, Meisel D. Adsorption and surface-enhanced raman of dyes on silver and gold sols. J Phys Chem. 1982;86:3391-3395.

28. Tejamaya M, Romer I, Merrifield RC, Lead JR. Stability of citrate, PVP, and PEG coated silver nanoparticles in ecotoxicology media. Environ Sci Technol. 2012;46(13):7011-7017.

29. Kim YS, Song SY, Park JD, et al. Subchronic oral toxicity of silver nanoparticles. Particle and Fibre Toxicol. 2010;7(1):20-32.

30. Kim YR, Park JI, Lee EJ, et al. Toxicity of $100 \mathrm{~nm}$ zinc oxide nanoparticles: a report of 90-day repeated oral administration in Sprague Dawley rats. Int J Nanomedicine. 2014;9(2):109-126.

31. Bearden HJ, Fuquay JW. Semen evaluation. In: Bearden HJ, Fuquay JW, editors. Applied Animal Reproduction. 4th ed. Upper Saddle River, NJ: Prentice Hall; 1997:158-169.

32. Łącka K, Kondracki S, Iwanina M, Wysokińska A. Assessment of stallion semen morphology using two different staining methods, microscopic techniques, and sample sizes. J Vet Res. 2016;60:99-104.

33. Kondracki S, Wysokińska A, Kania M, Górski K. Application of two staining methods for sperm morphometric evaluation in domestic pigs. J Vet Res. 2017;61:345-349.

34. Beutler E, Duron O, Kelly BM. Improved method for the determination of blood glutathione. J Lab Clin Med. 1963;61:882-888.

35. Fossati P, Prencipe L, Berti G. Use of 3, 5-dichloro-2-hydroxybenzene sulfonic acid/4-aminophenazone chromogenic system in direct enzyme assay of uric acid in serum and urine. Clin Chem. 1980;26(2):227-231.

36. Livingstone DR, Garcia-Martinez P, Michel X, et al. Oxyradial production as a pollution-mediated mechanics of toxicity in the common mussel, Mytilus edulis, and other mollusks. Funct Ecol. 1990;4:415-424.

37. Demetrious JA. Testosterone. In: Pesce AJ, Kapalan LA, editors. Methods in Clinical Chemistry. St Louis, MO, USA: Mosby; 1987:268.

38. Beastall GH. Immunoassay in the clinical chemistry laboratory. Lab Pract. 1985;34:74-81.

39. Tice RR, Agurell E, Anderson D, et al. Single cell gel/Comet assay: guidelines for in vitro and in vivo genetic toxicology testing. Environ Mol Mutagen. 2000;35(3):206-221.

40. Bancroft JD, Gamble M. Theory and Practice of Histological Techniques. 6th ed. Churchill Livingstone: Elsevier; 2008.

41. Baki ME, Miresmaili SM, Pourentezari M, Amraii E, Yousefi V, Spenani HR. Effects of silver nano-particles on sperm parameters, number of Leydig cells, and sex hormones in rats. Iran J Reprod Med. 2014;12(2):139-144.

42. Mathias FT, Romano RM, Kizys MM, Kasamatsu T, Giannòcco G, Chiamola MI. Daily exposure to silver nanoparticles during prepubertal development decreases adult sperm and reproductive parameters. Nanotoxicology. 2015;9(1):64-70.
43. Lafuente D, Garcia T, Blance J, Sánchez DJ, Sirvent JJ, Domingo JL. Effects of oral exposure to silver nanoparticles on the sperm of rats. Reprod Toxicol. 2016;60:133-139.

44. Fathi N, Hoseinipanah SM, Alizadeh Z, et al. The effect of silver nanoparticles on the reproductive system of adult male rats: a morphological, histological and DNA integrity study. Advan Clin Exp Med. 2019;28(3):299-305.

45. Carlson C, Hussain SM, Schrand AM, Braydich-Stolle LK, Hess KL, Jones RL. Unique cellular interaction of silver nanoparticles: size-dependent generation of reactive oxygen species. J Phys Chem B. 2008;112(43):13608-136019.

46. Sleiman HK, Romano RM, Oliveira CA, Romano MA. Effects of prepubertal exposure to silver nanoparticles on reproductive parameters in adult male Wistar rats. $J$ Toxicol Environ Health A. 2013;76:1023-1032.

47. Birben E, Sahiner UM, Sackesen C, Erzurum S, Kalayci O. Oxidative stress and antioxidant defense. World Allergy Organ J. 2012;5 (1):9-19.

48. Kirkman HN, Rolfo M, Ferraris AM, Gaetani GF. Mechanisms of protection of catalase by NADPH. Kinetics and stoichiometry. $J$ Biol Chem. 1999;274(20):13908-13914.

49. Pena-Llopis S, Ferrando MD, Pena JB. Fish tolerance to organophosphate-induced oxidative stress is dependent on the glutathione metabolism and enhanced by $\mathrm{N}$-acetylcysteine. Aquat Toxicol. 2003;65(4):337-360.

50. Zhang J, Shen H, Wang X, Wu J, Xue Y. Effects of chronic exposure of 2,4-dichlorophenol on the antioxidant system in liver of freshwater fish Carassius auratus. Chemosphere. 2004;55(2):167-174.

51. Liu Y, Wang JS, Wei Y, Zhang H, Xu M, Dai J. Induction of time-dependent oxidative stress and related transcriptional effects of perfluorododecanoic acid in zebrafish liver. Aquat Toxicol. 2008;89 (4):242-250.

52. Pandey S, Parvez S, Ansari RA, et al. Effects of exposure to multiple trace metals on biochemical, histological and ultrastructural features of gills of a freshwater fish, Channa punctata Bloch. Chem Biol Interact. 2008;174(3):183-192.

53. Nel A, Xia T, Mädler L, Li N. Toxic potential of materials at the nanolevel. Science. 2006;311(5761):622-627.

54. Bressan E, Vindigni V, Ferroni L, et al. Silver nanoparticles and mitochondrial interaction. Int J Dentistry. 2013. doi:10.1155/2013/312747

55. Yoshida Y, Itoh N, Saito Y, Hayakawa M, Niki E. Application of water-soluble radical initiator, 2, 2- azobis [2-(2-imidazolin- 2- yi) propane] dihydrochloride, to a study of oxidative stress. Free Radic Res. 2004;38(4):375-384.

56. Manin OI, Nikolaev VA, Kolomiitsev AA, Lebedenko I. Comparative toxicological evaluation of domestic golden alloys for soldering. Stoma Tologiia. 2007;86(1):64-67.

57. Girotti AW. Mechanisms of lipid peroxidation. J Free Radic Biol Med. 1985;1(2):87-95.

58. Arisha AM, Ahmed MM, Kamel MA, Attia YA, Hussein MMA. Morin ameliorates the testicular apoptosis, oxidative stress, and impact on blood-testis barrier induced by photo-extracellularly synthesized silver nanoparticles. Environ Sci Pollution Res. 2019;26 (28):28749-28762.

59. Elsharkawy EE, Abd El-Nasser M, Kamaly HF. Silver nanoparticles testicular toxicity in rat. Environ Toxicol Pharmacol. 2019;70:103194.

60. Egwurugwu JN, Ifedi CU, Uchefuna RC, Ezeokafor EN, Alagwu EA. Effects of zinc on male sex hormones and semen quality in rats. Niger J Physiol Sci. 2013;28(1):17-22.

61. Faccio L, Da Silva AS, Tonin AA, et al. Serum levels of LH, FSH, estradiol and progesterone in female rats experimentally infected by Trypanosoma evansi. Exp Parasitol. 2013;135(1):110-115.

62. Rezaei-Zarchi S, Taghavi-Foumani H, Negahdary M. Effect of silver nanoparticles on the $\mathrm{LH}, \mathrm{FSH}$ and testosterone hormones in male rat. J Babol Univ Med Sci. 2013;15(1):25-29. 
63. Trickler WJ, Burks S, Murdock RC, et al. Silver nanoparticle-induced Blood-Brain Barrier inflammation and increased permeability in primary rat brain micro-vessel endothelial cells. Toxicol Sci. 2010;118 (1):160-170

64. Liao W, McNutt MA, Zhu W. The comet assay: a sensitive method for detecting DNA damage in individual cells. Methods (San Diego, Calif). 2009;48(1):46-53.

65. AshaRani PV, Mun GK, Hande MP, Valiyaveettil S. Cytotoxicity and genotoxicity of silver nanoparticles in human cells. ACS Nano. 2009;3(2):279-290.

66. Singh R, Lillard JW. Nanoparticle-based targeted drug delivery. Exp Mol Pathol. 2009;86(3):215-223.

67. Yoshida S, Hiyoshi K, Ichinose T, et al. Effect of nanoparticles on the male reproductive system of mice. Int J Androl. 2009;32(4):337-342.

68. Thakur M, Gupta H, Singh D, Mohanty I, Maheswari U, Vanage G. Histopathological and ultrastructural effects of nanoparticles on rat testis following 90 days (chronic study) of repeated oral administration. J Nanobiotechnol. 2014;12:42.
69. El-Maddawy ZK, Abd El Naby WSH. Protective effects of zinc oxide nanoparticles against doxorubicin-induced testicular toxicity and DNA damage in male rats. Toxicol Res (Camb). 2019;8 (5):654-662.

70. Mohamed DA, Abdelrahman SA. The possible protective role of zinc oxide nanoparticles ( $\mathrm{ZnO}-\mathrm{NPs}$ ) on testicular and epididymal structure and sperm parameters in nicotine-treated adult rats (a histological and biochemical study). Cell Tissue Res. 2018. doi:10.1007/s00441-0182909-8

71. Fathi M, Haydari M, Tanha T. Effects of zinc oxide nanoparticles on antioxidant status, serum enzymes activities, biochemical parameters and performance in broiler chickens. J Livestock Sci Technol. 2016;4 (2):7-13.

\section{Publish your work in this journal}

The International Journal of Nanomedicine is an international, peerreviewed journal focusing on the application of nanotechnology in diagnostics, therapeutics, and drug delivery systems throughout the biomedical field. This journal is indexed on PubMed Central, MedLine, CAS, SciSearch ${ }^{\mathbb{R}}$, Current Contents ${ }^{\mathbb{R}} /$ Clinical Medicine, $^{-}$
Journal Citation Reports/Science Edition, EMBase, Scopus and the Elsevier Bibliographic databases. The manuscript management system is completely online and includes a very quick and fair peer-review system, which is all easy to use. Visit http://www.dovepress.com/ testimonials.php to read real quotes from published authors. 